John Carroll University Carroll Collected

Economics \& Finance

$10-1996$

\title{
Is the "Dominant Firm" Dominant? An Empirical Analysis of AT\&T'S Market Power
}

\author{
Simran K. Kahai \\ John Carroll University, skahai@jcu.edu \\ David L. Kaserman \\ John W. Mayo
}

Follow this and additional works at: http://collected.jcu.edu/econ_fin-facpub

Part of the Economics Commons, and the Finance and Financial Management Commons

\section{Recommended Citation}

Kahai, Simran K.; Kaserman, David L.; and Mayo, John W., "Is the “Dominant Firm” Dominant? An Empirical Analysis of AT\&T’S Market Power" (1996). Economics \& Finance. 5.

http://collected.jcu.edu/econ_fin-facpub/5 


\title{
IS THE "DOMINANT FIRM” DOMINANT? AN EMPIRICAL ANALYSIS OF AT\&T'S MARKET POWER*
}

\author{
SIMRAN K. KAHAI, \\ Auburn University \\ DAVID L. KASERMAN, \\ Auburn University \\ and \\ JOHN W. MAYO \\ University of Tennessee
}

\begin{abstract}
In this article, we estimate the degree of market power held by AT\&T in the interstate long-distance market in the postdivestiture period. Our approach makes use of the dominant firm/competitive fringe model to impose the structure needed both to obtain estimates of the relevant structural parameters and to translate these parameters into an estimate of AT\&T's residual demand elasticity and associated Lerner index. Because of the continued presence of regulation and other considerations, however, a direct estimation of the residual demand elasticity is not feasible. Consequently, we take a more indirect approach that combines estimation of the elasticity of fringe firm supply, market demand estimation, and extant market share data to generate estimates of the desired elasticity. The resulting estimates strongly support the conclusion that AT\&T lacks significant market power in the postdivestiture long-distance market.
\end{abstract}

\section{INTRODUCTION}

$\mathrm{O}$ NE of the most important policy issues in the telecommunications industry over the past decade and today has been the degree of market power held by AT\&T. This issue has been the subject of extensive debate in regulatory hearing rooms throughout the country, before state and federal legislative bodies, and in the economics literature. Divergent opinions concerning this question have influenced regulatory decisions and legislative proposals ranging from relaxed regulation of this firm to removal of the restriction on entry by the Bell operating companies (BOCs) into the in-

* The authors would like to thank John Jackson, Michael Ward, Sam Peltzman, an unnamed editor, and the anonymous referees for valuable insights and comments on earlier versions of this article. We retain sole responsibility for any remaining errors.

[Journal of Law and Economics, vol. XXXIX (October 1996)]

(C) 1996 by The University of Chicago. All rights reserved. 0022-2186/96/3902-0005 $\$ 01.50$ 
terLATA market. ${ }^{1}$ Indeed, it is difficult to imagine another applied microeconomics question that is likely to have as profound an effect on our public policy toward this industry in the coming years.

To date, however, virtually all evaluations of AT\&T's market power have been based on a more-or-less traditional antitrust analysis of the market structure within which this firm operates. ${ }^{2}$ That is, these evaluations have relied on evidence pertaining to structural characteristics such as market share and barriers to entry to reach judgmentally based conclusions about the degree of control over price that AT\&T is likely to possess in a deregulated environment. Substantial differences of opinion have emerged from these analyses. ${ }^{3}$ To a large extent, these differences may be traced to different implicit weights that the individual economists and regulatory agencies have attached to these various structural attributes (for example, market share versus entry conditions) and divergent expectations with respect to the likelihood of concerted action on the part of firms in this industry.

New developments in the economics literature over the past decade have

1 This restriction is contained in the 1982 divestiture order. See Modification of Final Judgment, United States of America v. Western Electric Company and American Telephone and Telegraph Company, Civil Action No. 82-0192, with Revisions as of January 1, 1989. Most recently, the Telecommunications Act of 1996 defines conditions under which the Bell operating companies will be permitted to provide interLATA services. LATA is an acronym for local access and transport area.

${ }^{2}$ For an exception, see Michael R. Ward, Measurements of Market Power in Long Distance Telecommunications (staff report, Federal Trade Commission, Bureau of Economics, Washington, D.C., 1995).

${ }^{3}$ Several of these studies have appeared over the past few years reaching diametrically opposing conclusions regarding the intensity of competition in this market. Studies that argue that significant market power is present include Jerry A. Hausman, The Long Distance Industry Today (unpublished manuscript, Mass. Inst. Tech. 1993); Steven C. Salop, Steven R. Brenner \& Gary L. Roberts, Market Power in the Supply of Long-Distance Services (unpublished manuscript, Charles River Associates 1990); Paul A. MacAvoy, Tacit Collusion under Regulation in the Pricing of Interstate Long-Distance Telephone Services, 4 J. Econ. \& Mgmt. Strategy 147, 185 (1995); and William G. Shepherd, Long-Distance Telephone Service: Dominance in Decline? in Industry Studies (Larry L. Duetsch ed. 1993).

Studies that posit the presence of effective competition include Michael L. Katz \& Robert D. Willig, The Case for Freeing AT\&T, Regulation, 43, 49 (1983); David L. Kaserman \& John W. Mayo, Long Distance Telecommunications Policy: Rationality on Hold, 122 Pub. Util. Fort. 18, 27 (1988); Michael E. Porter, Competition in the Long Distance Telecommunications Market (unpublished report, Monitor Company 1993); Robert E. Hall, Long Distance: Public Benefits from Increased Competition (unpublished manuscript, Applied Economic Partners, Menlo Park, Calif. 1993); David L. Kaserman \& John W. Mayo, Long-Distance Telecommunications: Expectations and Realizations in the Post-divestiture Period, in Incentive Regulation for Public Utilities (Michael A. Crew ed. 1994); and David L. Kaserman \& John W. Mayo, Competition and Asymmetric Regulation in Long-Distance Telecommunications: An Assessment of the Evidence, 4 Comm L. Conspectus 1, 26 (Winter 1996). These studies serve to highlight the importance of this debate and the glaring need for empirical work in this area. 
produced an alternative, econometrically based, approach to the evaluation of market power. ${ }^{4}$ Several alternative econometric techniques have been introduced to estimate the extent to which individual firms' output decisions influence market price. Implementing one or more of these techniques can, under certain conditions, yield an estimate of the price elasticity of the individual firm's residual demand curve. The inverse of this elasticity, then, provides a direct estimate of the Lerner index of the degree of monopoly power held by that firm.

In this article, we estimate the residual demand elasticity and associated Lerner index for AT\&T in the interstate long-distance market in the postdivestiture period. Because of the continued presence of regulation and other considerations, however, direct estimation of this elasticity along traditional lines is not feasible. Consequently, we take a more indirect approach that utilizes estimates of the underlying components of the desired elasticity. This approach makes use of the dominant firm/competitive fringe (DF/CF) model to impose the structure needed both to obtain estimates of the relevant structural parameters and to translate these parameters into an estimate of AT\&T's residual demand elasticity and Lerner index.

The resulting estimates strongly support the conclusion that AT\&T lacks significant market power in the postdivestiture long-distance market. While such evidence is not likely to completely resolve the ongoing debate about the appropriate regulatory policy for this industry, it should contribute to the overall quality of that debate by adding an alternative empirical approach that is well founded in modern econometric methods of estimating market power.

The article is organized as follows. In Section II, we describe various conceptual considerations related to formulation of the empirical model. In Section III, we provide a description of the data and present our estimation results. The residual demand elasticity estimates and market power calculations are then reported and interpreted in Section IV. Finally, in Section $\mathrm{V}$, we provide conclusions and discuss several caveats that accompany our analysis.

\section{Conceptual Considerations and Model Specification}

Under certain conditions, natural market events may generate data that allow researchers to draw inferences about the percentage departure of price from marginal cost, even though the relevant marginal opportunity costs are

\footnotetext{
${ }^{4}$ See, for example, the papers included in the issue-length conference on "Empirical Approaches to Market Power,' 32 J. Law \& Econ. (October 1989). Also, see Timothy F. Bresnahan, Empirical Studies of Industries with Market Power, in 2 Handbook of Industrial Organization (Richard Schmalensee \& Robert Willig eds. 1989).
} 
generally unobservable. When such events occur, fairly generalized models of industry demand functions and individual firms' supply relations can yield estimates of structural parameters that shed light on the type of behavior exhibited by market participants, that is, whether the firms are colluding or competing. ${ }^{5}$

Within this class of models, an important approach has been estimation of firms' residual demand elasticities. ${ }^{6}$ Because of the functional relationship that exists between the individual firm's price elasticity of residual demand and the Lerner index of market power, estimation of a company's residual demand curve provides a direct method of calculating the degree of market power it enjoys.? Therefore, to evaluate the extent of AT\&T's market power in the postdivestiture long-distance market, we estimate the price elasticity of this firm's residual demand. ${ }^{8}$ To provide the structure necessary to evaluate the degree of AT\&T's market power in the interstate long-distance market, we make use of the $\mathrm{DF} / \mathrm{CF}$ model. The principal assumptions of this model are (1) there is one firm that holds a relatively large share of the market (that is, the dominant firm); (2) there is a competitive fringe, consisting of a large number of much smaller firms, each of which takes the dominant firm's price as given; and (3) the product is homogeneous.

These assumptions appear to be reasonably well satisfied in the longdistance market during the time period covered by our data, 1984-93. First, during this period, AT\&T continued to hold a relatively large share of the long-distance market. In particular, while there was a noticeable decline in AT\&T's minutes-of-use market share, from 84 to 59 percent, the average share was 72 percent over this period. ${ }^{9}$ As a point of reference, some eco-

${ }^{5}$ See Bresnahan, supra note 4 , for a survey.

${ }^{6}$ See Jonathon B. Baker \& Timothy F. Bresnahan, Empirical Methods of Identifying and Measuring Market Power, 61 Antitrust L. J. 3, 16 (1991). For an application of residual demand estimation, see Jonathon B. Baker \& Timothy F. Bresnahan, Estimating the Residual Demand Curve Facing a Single Firm, 6 Int'l J. Indus. Org. 283, 300 (1988).

${ }^{7}$ Residual demand estimation has also been applied to the issue of market definition. See David T. Scheffman \& Pablo T. Spiller, Geographic Market Definition under the U.S. Department of Justice Merger Guidelines, 30 J. Law \& Econ. 123, 147 (1987).

${ }^{8}$ Direct estimation of residual demand in this market environment, however, is precluded. As explained by Baker \& Bresnahan, supra note 6, at 7, estimation of residual demand functions requires identification of exogenous variables that shift one firm's marginal costs without affecting the costs of other firms in the industry. Firms competing in the long-distance market, however, all purchase essentially the same set of inputs at roughly equivalent prices. Consequently, AT\&T has not experienced the sort of independent cost shifts that would allow identification of its residual demand curve from the available data. Additional structure must, therefore, be imposed on the model to permit this estimation.

${ }^{9}$ See Federal Communications Commission (FCC), Statistics of Communications Common Carriers, 1993/1994 ed. (released February 1995). 
nomics literature suggests a threshold market share value of 40 percent in their treatment of the dominant firm model..$^{10}$ Also, consistent with the model's assumptions, during this period AT\&T faced a considerably fragmented set of individually relatively small competitors. In 1986, AT\&T faced roughly 170 competitors. ${ }^{11}$ By 1993 , that number had grown to $440 .{ }^{12}$ At the beginning of the sample period, no single competitor to AT\&T provided more than 6 percent of the interstate long-distance traffic.

As the industry structure has evolved over time, AT\&T's two largest competitors, MCI and Sprint, have grown considerably. At the beginning of the sample period, the revenue-based market shares of these two firms were 5.5 and 2.6 percent, respectively. In 1988 , these market shares were 10.3 and 7.2 percent, and by 1993 they had grown to 17.8 and $10.0 .{ }^{13}$ The dominant firm model assumes that the fringe competitors are individually small enough that they accept the price of the dominant firm as given in determining their supply response. The classification of MCI and Sprint as fringe firms is admittedly a matter of judgment. We believe, however, it is justified by the relatively new positions of these firms in the market and their relatively small market shares during the period in question. As these firms continue to grow, it becomes increasingly less clear by the mid-1990s that the long-distance industry still conforms well to the assumptions of the DF/CF model. ${ }^{14}$

Another important benchmark for the application of the DF/CF model is the degree of product homogeneity. In a pure DF/CF model, all of the firms' products are perfectly homogeneous. Clearly, this is a simplifying abstraction that is rarely, if ever, met in empirical modeling. At the same time, application of the theoretical model should be applied to industries that at least approximately conform to the assumption. The relatively comparable levels of transmission speeds and quality, functions and features of

${ }^{10}$ See F. M. Scherer \& David Ross, Industrial Market Structure and Economic Performance (3d ed. 1990).

11 FCC, supra note 9.

${ }^{12}$ Id. Also, firm structure varies considerably across these competitors. Some carriers (for example, MCI and Sprint) are vertically integrated with both underlying transmission facilities and retail service offerings. Others participate exclusively at the wholesale stage (the socalled carriers' carriers,) or retail stage (that is, resellers).

${ }^{13}$ See Federal Communications Commission (FCC), Common Carrier Bureau, Industry Analysis Division, Trends in Telephone Service, February 1995.

${ }^{14}$ The observed evolution of the industry structure in the long-distance market is consistent with a literature beginning with Dean A. Worcester, Why "Dominant" Firms Decline, $65 \mathrm{~J}$. Pol. Econ. 338, 346 (1957), wherein it is argued that the dominant firm case is inherently unstable and that such industries will, over time, evolve to alternative market structures. Thus, the "window of opportunity" to analyze the long-distance, or any, industry in light of the DF/CF model may be innately limited. 
long-distance calling in the postdivestiture period, together with an observed willingness of consumers to switch long-distance carriers, provides a relatively compelling prima facie case that consumers view long-distance services as essentially homogeneous. ${ }^{15}$

Additionally, however, the pure DF/CF model that assumes perfect product homogeneity may be modified to account for any tangible sources of product differentiation that may be part of the industry in question. ${ }^{16}$ In the case of the long-distance market over the 1984-93 period, the primary source of product differentiation was the lack of dialing parity between AT\&T and its competitors. Specifically, in the absence of switching upgrades by the local exchange companies, known as "equal access," AT\&T uniquely enjoyed " $1+$ " dialing at the time of the divestiture. In the absence of equal access, customers of all other long-distance companies were forced to dial additional digits to access their long-distance carrier before dialing the number of the party with whom they wished to speak. Beginning in 1984 , and continuing throughout the sample period, however, local exchange companies have increasingly deployed equal access in their central office switches. By the end of the sample period, 97 percent of all telephone lines nationwide were converted to equal access. ${ }^{17}$ Coincident with the proliferation of equal access and the increasing recognition of product homogeneity in the supply of long-distance services, the prices of these services have rapidly

15 The comparability of the technical quality of long-distance service provided by interexchange firms is well established. See, for example, Mary Jander, Users Rate Long-Distance, 22 Data Comm. 89, 92 (1993). Evidence of consumers' willingness to switch long-distance carriers is found in Robert E. Allen, Testimony before the United States Committee on Commerce, Science and Transportation, Subcommittee on Telecommunications, September 8, 1993, wherein it is noted that in 1992, over 16 million customers switched their long-distance carriers. Advertising is a potential source of product differentiation. Several points, however, indicate that the advertising in the long-distance market is not a significant impediment to the applicability of the DF/CF model. First, virtually all industries engage in advertising. To the extent that advertising provides information regarding, say, pricing, its presence should not be a seen as indicative of significant product differentiation. Second, while advertising is common in the long-distance market, it was not, by U.S. advertising standards, "intense" during the sample period. For example, advertising to sales ratios for AT\&T for the 198488 period were roughly 1 percent. No major carrier's advertising to sales ratio exceeded 5 percent over this period. See Porter, supra note 3. Finally, the proliferation of customer switching indicates that, although there is considerable effort by long-distance carriers to engender brand loyalty, advertising has not, in fact, created significant product differentiation.

${ }^{16}$ For examples of empirical DF/CF models that have successfully accounted for elements of intraindustry product differentiation, see Valerie Suslow, Estimating Monopoly Behavior with Competitive Recycling: An Application to ALCOA, 17 RAND J. Econ. 389, 403 (1986); and Larry R. Blank, David L. Kaserman, \& John W. Mayo, Dominant Firm Pricing with Competitive Entry and Regulation: The Case of IntraLATA Toll (unpublished manuscript, Univ. Tennessee 1995).

${ }^{17}$ FCC, supra note 13, table 12, p. 20. 
converged over time. ${ }^{18}$ In sum, for the $1984-93$ period, the fundamental characteristics of the long-distance market conform reasonably well with the assumptions underlying the DF/CF model. The empirical model specified below, however, accounts for any potential product differentiation in the long-distance market caused by the lack of ubiquitous equal access.

Given the DF/CF model, the residual demand curve faced by AT\&T is given by the total market demand curve minus the collective supply curve of the competitive fringe; that is,

$$
Q_{\text {ATT }}(P)=Q_{\mathrm{M}}(P)-Q_{\mathrm{F}}(P),
$$

where $P$ is the price of long-distance service, $Q_{\mathrm{ATT}}(P)$ is AT\&T's residual demand, $Q_{\mathrm{M}}(P)$ is market demand, and $Q_{\mathrm{F}}(P)$ is fringe supply. Due to the price-taking behavior exhibited by fringe producers, $Q_{\mathrm{F}}(P)$ is given by the collective marginal cost curve of these firms. Equation (1) may be manipulated to obtain the dominant firm's residual demand elasticity as a function of three underlying structural parameters:

$$
\eta_{\mathrm{ATT}}=\frac{\eta_{\mathrm{M}}}{S_{\mathrm{ATT}}}+\frac{\left(1-S_{\mathrm{ATT}}\right) \epsilon_{\mathrm{F}}}{S_{\mathrm{ATT}}},
$$

where $\eta_{\text {ATT }}$ is AT\&T's residual demand elasticity, $\eta_{M}$ is the market demand elasticity, $S_{\mathrm{ATT}}$ is AT\&T's market share, and $\epsilon_{\mathrm{F}}$ is the price elasticity of fringe supply. ${ }^{19}$

Equation (2) may be used to calculate $\eta_{\mathrm{ATT}}$ from prior estimates of three underlying structural parameters $-\eta_{\mathrm{M}}, \epsilon_{\mathrm{F}}$, and $S_{\mathrm{ATT}}$. Estimates of $S_{\mathrm{ATT}}$ and $\eta_{M}$ are readily available in the published literature. No such estimates of $\epsilon_{F}$, however, exist. In fact, one could argue that the absence of such an estimate is the principal source of the ongoing debate regarding the intensity of competition (and, therefore, optimal regulatory policy) in this market. Therefore, in order to implement equation (2), we must first estimate the price elasticity of fringe supply.

Toward this end, we specify a simultaneous model of competitive fringe supply and market demand in the interstate long-distance market. The the-

${ }^{18}$ See Kaserman \& Mayo, Long-Distance Telecommunications, supra note 3, for evidence of convergence of prices for intrastate toll services. A similar convergence has occurred for interstate services. Indeed, a review of the rates charged for basic residential message toll service between various locations in 1993 reveals that the these prices for AT\&T, MCI, and Sprint are virtually identical. See FCC, supra note 9, tables 7.1-7.3.

${ }^{19}$ See Thomas R. Saving, Concentration Ratios and the Degree of Monopoly, 11 Int'l Econ. Rev. 139, 146 (1970). 
ory of supply suggests the following general specification for the inverse supply curve of the fringe:

$$
P=P_{\mathrm{F}}\left(Q_{\mathrm{F}}, P A, E A\right) .
$$

Here, $Q_{\mathrm{F}}$ is the fringe output, $P A$ is the price long-distance firms pay to the local exchange companies on a minutes-of-use basis for access to the local network, and $E A$ is the percentage of telephone lines converted to equal access. Carrier access is the predominant input required for the production of long-distance service, generally accounting for over half of these firms' total costs (and even more of their marginal costs). Thus, $\partial P_{\mathrm{F}} / \partial P A>0$ is expected to hold.

As noted above, the primary source of product differentiation in the postdivestiture long-distance industry has been the lack of dialing parity between AT\&T and its rivals. To explicitly account for this element of product differentiation, we include a measure of the proliferation of equal access $(E A)$ in the long-distance industry over time. We expect that, as the degree of product homogeneity increases with growth in the extent of equal access, the ability of fringe suppliers to expand their output is increased, ceteris paribus, and price pressure on the dominant firm will grow. Accordingly, we expect that $\partial P_{\mathrm{F}} / \partial E A<0$. That is, equal access shifts fringe supply outward.

Finally, because fringe supply is expected either to slope upward or to be horizontal, $\partial P_{\mathrm{F}} / \partial Q_{\mathrm{F}} \geq 0$ should hold. It is this last parameter, of course, that is the primary focus of our attention, because it reveals the ability and willingness of AT\&T's competitors to enter and expand in response to any attempted price increases. That ability, in turn, is a primary determinant of AT\&T's market power. The closer this parameter is to zero (that is, the more elastic is fringe supply), the lower are barriers to entry and expansion and, therefore, the greater the intensity of potential competition. Conversely, a large positive coefficient on $Q_{\mathrm{F}}$ would indicate a relatively inelastic fringe supply with comparatively ineffective potential competition.

Turning to the inverse market demand function for long-distance service, we specify

$$
P=P_{\mathrm{M}}\left(Q_{\mathrm{M}}, P_{\mathrm{L}}, \text { PHONE, PHONESQ, } Y, D_{i}\right),
$$

where $Q_{\mathrm{M}}$ is the market quantity, $P_{\mathrm{L}}$ is an index of real prices for local telephone service, PHONE is the number of U.S. households that subscribe to telephone service, PHONESQ is the square of PHONE, $Y$ is real per capita income, and $D_{i}$ is a vector of three quarterly dummies. We expect market demand to slope downward. We expect increases in the price of local telephone service to reduce the demand for long-distance service due to the 
complementary nature of these products. ${ }^{20} \mathrm{We}$ expect increases in household subscribership generally to increase market demand. We allow for a nonlinear (quadratic) relationship between subscribership and demand due to the network characteristic of telecommunications consumption-a doubling of subscribers is likely to more than double the market demand. Finally, we expect increases in income to increase long-distance demand. Thus, our hypotheses regarding equation (4) are that $\partial P_{\mathrm{M}} / \partial Q_{\mathrm{M}}<0, \partial P_{\mathrm{M}} /$ $\partial P_{\mathrm{L}}<0, \partial P_{\mathrm{M}} / \partial \mathrm{PHONE}>0$, and $\partial P_{\mathrm{M}} / \partial Y>0$. No hypotheses are expressed with respect to $D_{i}$. Our primary interest will be in the parameter associated with $Q_{\mathrm{M}}$ due to its relationship to the market price elasticity of demand and the corresponding relationship of that elasticity to the Lerner index.

Equations (3) and (4) constitute a simultaneous DF/CF model with $P$, $Q_{\mathrm{M}}$, and $Q_{\mathrm{F}}$ endogenous. The exogenous variables included in this system are $P A, E A, P_{\mathrm{L}}$, PHONE, PHONESQ, $Y$, and $D_{i \cdot}{ }^{21}$ Estimation of these two structural relationships provides estimates of $\eta_{\mathrm{M}}$ and $\epsilon_{\mathrm{F}}$ that, together with observed values of $S_{\text {ATT }}$, can be used to calculate $\eta_{\text {ATT }}$ via equation (2). This elasticity of residual demand, in turn, can be used to calculate the Lerner index for AT\&T in the postdivestiture period.

\section{Data AND Estimation Results}

Within the framework of the DF/CF model, the market price, the quantity supplied by fringe firms, and the market quantity are determined simultaneously. Thus, estimation of the fringe supply and market demand functions with ordinary least squares would produce inconsistent and biased parameter estimates. Accordingly, we utilize two-stage least squares (2SLS) to estimate the model. The data used for this estimation are quarterly observations covering the time period from 1984:3 through 1993:4. Thus, our sample contains 38 observations. Appendix Table A1 provides our variable definitions and data sources.

Estimation results for the fringe supply curve in linear form with 2SLS are reported in Table $1 .^{22}$ The explanatory power of the model is quite high,

${ }^{20}$ Jerry Hausman, Timothy Tardiff, \& Alexander Belinfante, The Effects of the Breakup of AT\&T on Telephone Penetration in the United States, 83 Am. Econ. Rev. 178, 184 (1993), report empirical evidence of such complementarity.

${ }^{21}$ An examination of the estimating equations indicates that the fringe supply is overidentified and the market demand equation is exactly identified. In this context, two-stage least squares is an appropriate estimation technique. See, for example, Jan Kmenta, Elements of Econometrics (2d ed. 1986).

${ }^{22}$ The model was also estimated with three-stage least squares (3SLS). Because the 3SLS results are virtually identical to the 2 SLS results, we report only the latter here. Also, the model was estimated using both linear and double-log specifications. Because the basic results are invariant to the specification, we report the estimations from the linear specification. 
TABLE 1

Inverse Fringe Supply Equation: Two-Stage Least SQUARES EsTIMATES

\begin{tabular}{|c|c|c|}
\hline Variables & Coefficient & $t$-Statistic \\
\hline Intercept & .059 & $1.921 * *$ \\
\hline$Q_{\mathrm{F}}$ & .002 & $3.346^{*}$ \\
\hline$P A$ & 1.860 & $11.293^{*}$ \\
\hline$E A$ & -.001 & $-6.173^{*}$ \\
\hline$R^{2}$ & .99 & \\
\hline
\end{tabular}

and all coefficients attain the expected signs. Moreover, all parameters are statistically significant. The positive sign on the coefficient of $Q_{\mathrm{F}}$ indicates an upward-sloping fringe supply. The positive sign on the coefficient of $P A$ suggests that fringe supply shifts backward with increases in the price of the principal input (that is, access). The negative sign attached to the coefficient of EA confirms our expectation that the provision of equal access and the commensurate decreases in the degree of product differentiation increase fringe supply.

Most important, the 2SLS results produce a fringe supply elasticity estimate of 4.38 at the sample means. Thus, our results suggest a large supply response to a price change on the part of fringe firms in this industry. ${ }^{23}$ This finding, in turn, is consistent with prior arguments that have posited an absence of significant barriers to entry and expansion in this industry. ${ }^{24}$

Next, Table 2 reports our estimation results for the interstate longdistance telecommunications market demand function using 2SLS. Here, too, the results appear to be quite reasonable. The model exhibits considerable explanatory power, and all hypothesized coefficient signs are obtained.

${ }^{23}$ This finding that the elasticity of fringe firm supply in the long-distance industry is large is corroborated by an examination of marketplace data regarding barriers to entry and expansion of fringe firms in the postdivestiture period. Specifically, the phenomenal growth in the number of firms indicates that entry into the long-distance industry is not difficult. Moreover, these new entrants have sustained a decade-long compound annual growth rate (based on minutes sold) of roughly 20 percent, indicating that barriers to expansion are minimal. At the same time, the amount of capacity deployed in the long-distance market has expanded very rapidly. See Federal Communications Commission (FCC), Fiber Deployment UpdateEnd of Year 1993 (unpublished report, FCC, May 1994); and AT\&T Bell Laboratories, An Update Study of AT\&T's Competitors' Capacity to Absorb Rapid Demand Growth (unpublished manuscript, AT\&T, April 1995). As a consequence, fringe firms either own or have access to large amounts of capacity with which they can easily expand output.

${ }^{24}$ Katz \& Willig, supra note 3; Porter, supra note 3; and Kaserman \& Mayo (LongDistance Telecommunications Policy; Long-Distance Telecommunications; Competition and Asymmetric Regulation, all supra note 3), among others, have made such arguments. 
TABLE 2

InVerse Market Demand Equation: Two-Stage LEAST SQuares Estimates

\begin{tabular}{lcc}
\hline \hline Variables & Coefficient & $t$-Statistic \\
\hline Intercept & 9.313 & $5.747^{*}$ \\
$Q_{\mathrm{M}}$ & -.006 & $-4.655^{*}$ \\
$P_{\mathrm{L}}$ & -.003 & $-5.063^{*}$ \\
PHONE & -.206 & $-5.642^{*}$ \\
PHONESQ & .001 & $6.630^{*}$ \\
$Y$ & $1.07 \times 10^{-5}$ & $5.104^{*}$ \\
$D_{2}$ & .002 & .625 \\
$D_{3}$ & .009 & $2.152^{* *}$ \\
$D_{4}$ & .009 & $2.107^{*}$ \\
$R^{2}$ & .99 & \\
$F$ & 737.043 & \\
Durbin-Watson & 1.808 & \\
\hline
\end{tabular}

* Significant at the .01 level.

** Significant at the .05 level.

Moreover, all coefficients except the second-quarter dummy are significant at the .05 level or higher. These results confirm a downward-sloping market demand that declines with higher local telephone rates. The coefficients attached to PHONE and PHONESQ suggest a U-shaped relationship between subscribership and long-distance demand. At the sample mean, however, $\partial P / \partial \mathrm{PHONE}=0.0093>0$, and $\partial^{2} P / \partial \mathrm{PHONE}^{2}=0.002>0$. Thus, at these values, demand increases at an increasing rate as subscribership rises. This result is consistent with theoretical expectations for products subject to network externality effects. Finally, long-distance demand increases with per capita income (it is a normal good) and is significantly higher in the third and fourth quarters.

For our purposes, the result that is of primary importance is the market price elasticity of demand. At the sample means, the results reported in Table 2 yield an elasticity estimate of -0.49 . Given the time-series nature of our data, this estimate should correspond to a short-run demand elasticity. Accordingly, this figure conforms with, but is at the low end of the range of, elasticities for this market reported in a recent survey of telecommunications demand studies. ${ }^{25}$ Consequently, use of this relatively low market price elasticity estimate will tend to bias our Lerner index calculations upward.

${ }^{25}$ Lester D. Taylor, Telecommunications Demand in Theory and Practice 17 (1994), states that, "[i]n general, these new studies show price elasticities of -0.5 to -0.75 for interLATA (i.e., longer-haul) toll calling." Also, see J. P. Gatto et al., Intrastate Switched Access Demand, 3 Info. Econ. \& Pol'y 333, 358 (1988). 


\section{Residual Demand Elasticity and Market Power Calculations}

Given the above estimates of $\epsilon_{\mathrm{F}}$ and $\eta_{\mathrm{M}}$ and knowledge of AT\&T's market share, $S_{\mathrm{ATT}}$, we can calculate estimates of AT\&T's residual demand elasticity and corresponding estimates of the Lerner index for this firm. Market share figures are generally based upon either output or capacity. ${ }^{26}$ Federal Communications Commission figures indicate an output-based market share for AT\&T at the end of 1993 of 60 percent, while AT\&T's share of industry assets was equal to approximately 40 percent. $^{27}$

From these two alternative values of $S_{\text {ATT }}$, we can substitute the estimated values of $\epsilon_{F}$ and $\eta_{M}$ into equation (2). These substitutions yield values of AT\&T's residual demand elasticity of -3.73 and -7.81 , for the outputbased and capacity-based market shares, respectively. The corresponding values of the Lerner index $(\lambda)$, then, are .29 and .13. Given that the theoretical range of the Lerner index is from zero to unity, the relatively low values of these estimates suggest that AT\&T does not possess significant market power in the pricing of long-distance services. ${ }^{28}$

These Lerner index figures, however, are somewhat difficult to interpret in isolation. To gain a better perspective on what these numbers imply, it is useful to compare them with similar estimates for other industries. Fortunately, two recent studies provide a basis for such comparison. First, a paper by Hall reports estimates of the ratio of marginal cost to price for 26 U.S. industries. ${ }^{29}$ As seen in Table 3, Hall's estimates can easily be transformed into estimates of the Lerner index for these industries. ${ }^{30}$

${ }^{26}$ See, for example, the Department of Justice and Federal Trade Commission 1992 Horizontal Merger Guidelines, which, depending on the particular circumstances prevalent in a market, state that these agencies will use either total sales or capacity to calculate market shares. Capacity-based market share calculations have greater information content in the long-distance telecommunications market. See Herbert Hovenkamp, Antitrust Analysis of Market Power, with Some Thoughts about Regulated Industries, in Telecommunications Deregulation: Market Power and Cost Allocation Issues 7, 8 (John R. Allison \& Dennis L. Thomas eds. 1987).

${ }^{27}$ Output-based market shares are reported in FCC, supra note 9. An estimate of AT\&T's asset-based market share is found in John Haring \& Kathleen Levitz, What Makes the Dominant Firm Dominant? (working paper, Federal Communications Commission, Office of Plans and Policies 1989). Corroboration for the asset-based market share statistic is found in FCC, supra note 23; and AT\&T Bell Laboratories, supra note 23.

${ }^{28}$ Interestingly, Ward, supra note 2, uses an alternative econometric model and different data to quantify the magnitude of AT\&T's own-price elasticity and its associated Lerner index with results very similar to those reported here.

${ }^{29}$ See Robert E. Hall, The Relation between Price and Marginal Cost in U.S. Industry, 96 J. Pol. Econ. 921, 947 (1988).

${ }^{30}$ The study by Hall, id., is built on a number of simplifying assumptions and utilizes Census Bureau Standard Industrial Classification (SIC) definitions of industries. Thus, his estimates regarding the degree of market power in any particular industry should be inter- 
TABLE 3

Hall's Market Power Estimates for Other (Unregulated) Industries

\begin{tabular}{lccc}
\hline \hline & $\beta$ & $\lambda$ & $\eta$ \\
Industry & $(M C / P)$ & $(P-M C) / P=1-\beta$ & $P /(P-M C)=1 / \lambda$ \\
\hline Food and kindred products & .189 & .811 & 1.23 \\
Tobacco manufactures & .362 & .638 & 1.57 \\
Textile mill products & .388 & .612 & 1.63 \\
Apparel and other textile & 1.213 & -.123 & -4.69 \\
Lumber and wood products & .555 & .445 & 2.25 \\
Furniture and fixtures & .506 & .494 & 2.02 \\
Paper and allied products & .269 & .731 & 1.37 \\
Printing and publishing & .07 & .93 & 1.08 \\
Chemicals and allied products & .05 & .95 & 1.05 \\
Petroleum and coal products & -.007 & 1.007 & .99 \\
Rubber and miscellaneous & .663 & .337 & 2.97 \\
Leather and leather products & .476 & .524 & 1.91 \\
Stone, clay, and glass products & .394 & .606 & 1.65 \\
Primary metal industries & .46 & .54 & 1.85 \\
Fabricated metal products & .607 & .393 & 2.54 \\
Machinery, except electrical & .7 & .3 & 3.33 \\
Electrical and electronic & .324 & .676 & 1.48 \\
Instruments and related & .716 & .284 & 3.52 \\
Miscellaneous manufacturing & .223 & .777 & 1.29 \\
Communication & .028 & .972 & 1.02 \\
Electric, gas, and sanitary & .079 & .921 & 1.09 \\
Motor vehicles and equipment & .567 & .433 & 2.31 \\
Other transportation equipment & 1.053 & -.053 & -18.87 \\
Transportation & .251 & .749 & 1.34 \\
Wholesale trade &. .271 & .271 & .79 \\
Retail trade & .425 & .575 & 1.74 \\
\hline
\end{tabular}

Sources. - Robert E. Hall, The Relation between Price and Marginal Cost in U.S. Industry, 96 J. Pol. Econ. 921, 947 (1988); and authors' calculations.

Comparing Hall's estimates to our estimates for AT\&T, we find that, relative to these other industries, AT\&T possesses remarkably little market power. The mean value of our Lerner index estimates is .20 for AT\&T, while the mean of the 22 industries for which Hall's estimates fall within the theoretically acceptable range (that is, for which $0 \leq \lambda<1$ ) is .62 . Moreover, the maximum estimate of $\lambda$ we obtain for AT\&T is .29. This value is below every single industry in Hall's sample that generated a Lerner index value within the acceptable range, with the single exception of

preted cautiously. For example, local telephone exchange, long-distance, and cable television operations are combined to yield an aggregated estimate for "Communications." An additional caveat to the use of Hall's estimates stems from the fact that they are built on a data series that ends in 1984. Despite these caveats, Hall's Lerner index values nonetheless provide a useful benchmark for comparison purposes. 
TABLE 4

Bresnahan's Survey of Prior Empirical Estimates of LeRner Indices

\begin{tabular}{lll}
\hline \hline Author & \multicolumn{1}{c}{ Industry } & \multicolumn{1}{c}{$\lambda$} \\
\hline Lopez (1984) & Food processing & .504 \\
Roberts (1984) & Coffee roasting & $.055 / .025^{*}$ \\
Appelbaum (1982) & Rubber & .049 \\
Appelbaum (1982) & Textile & $.072 \dagger$ \\
Appelbaum (1982) & Electrical machinery & $.198 \dagger$ \\
Appelbaum (1982) & Tobacco & $.648 \dagger$ \\
Porter (1983) & Railroads & $.40 \ddagger$ \\
Slade (1987) & Retail gasoline & .10 \\
Bresnahan (1981) & Automobiles (1970s) & $.1 / .34 \S$ \\
Suslow (1986) & Aluminum (interwar) & .59 \\
Spiller-Favaro (1984) & Banks "before""\| & $.88 / .21^{\#}$ \\
Spiller-Favaro (1984) & Banks "after"\| & $.40 / .16^{\#}$ \\
\hline
\end{tabular}

SoURCE.-For full author citations, see Timothy F. Bresnahan, Empirical Studies of Industries with Market Power, in 2 Handbook of Industrial Organization (Richard Schmalensee \& Robert Willig eds. 1989).

* Largest and second largest firm, respectively.

$\dagger$ At sample midpoint.

When cartel was succeeding; 0 in reversionary periods.

$\S$ Varies by type of car; larger in standard, luxury segment.

\| Uruguayan banks before and after entry deregulation.

\# Large firms/small firms (see their table 2).

Instruments and Related Products. ${ }^{31}$ Thus, relative to these other industries (virtually all of which are unregulated), AT\&T appears to face very effective competition.

Finally, Bresnahan's survey of prior empirical studies of market power in individual industries presents a table summarizing the Lerner indices estimated by various authors. ${ }^{32}$ We reproduce the results of that survey in Table 4. Almost a dozen industries are represented. The range of estimated market power is quite broad, with the Lerner index ranging from a low of .025 to a high of .88 . Nonetheless, our estimates of AT\&T's Lerner index clearly fall toward the low end of the reported indices. The mean Lerner index reported in Bresnahan is .296, which is slightly above even our maximum estimate for AT\&T. Thus, this second comparison also supports the

${ }^{31}$ Stefan Norrbin, The Relation between Price and Marginal Cost in U.S. Industry: A Contradiction, 101 J. Pol. Econ. 1149, 1164 (1993), modifies Hall's analysis and generates considerably lower price-marginal cost markups and implied Lerner index values for U.S. industries. Even employing the values from Norrbin's analysis, however, AT\&T's Lerner index values are in the middle of the pack for nonregulated industries in the United States.

${ }^{32}$ See Bresnahan, supra note 4, at 1051, table 17.1. 
conclusion that, relative to other firms in the U.S. economy, AT\&T possesses very little market power.

\section{Conclusions and Caveats}

At the time of the divestiture of the BOCs from AT\&T, considerable debate emerged concerning the long-run viability of competition in the longdistance telecommunications industry. In the period since divestiture, that debate has shifted to a consideration of the intensity of competition faced by the former monopoly supplier of long-distance service. To date, however, the arguments presented have proceeded primarily on a priori theoretical grounds pertaining to conditions of natural monopoly and largely ad hoc analyses of the emerging structural characteristics of the industry. While evidence of this nature is valuable in attempting to resolve this important public policy issue, it is important to attempt to corroborate such information with empirical studies as the requisite data become available. In this spirit, we have employed the DF/CF model to estimate both fringe supply and market demand elasticities in the interstate long-distance telecommunications market. We have employed the resulting elasticity estimates along with extant information on AT\&T's market share to calculate empirical estimates of AT\&T's market power.

As with any empirical analysis, our results should be interpreted in the light of several caveats. First, our data series is relatively short, with only a 10-year window of observations. Ironically, given the empirical propensity of dominant firms to decline, the benefits of a longer time series may ultimately be offset by a declining applicability of the underlying DF/CF model to this industry. Thus, the window of opportunity for modeling this industry with the DF/CF model may be waning as the industry structure evolves.

Second, as with other industries that have experienced the transition from regulated monopoly to competition, new pricing structures are emerging in the long-distance industry that limit the relevance of "list" prices. A noticeable deviation of average revenue per minute (that is, the actual transactions price) of long-distance service sold and the basic tariffed price began to emerge at the end of our sample period with the introduction of a variety of discount pricing plans by long-distance suppliers. To the extent that competition has increasingly driven transactions prices below the basic tariffed prices used in this study, our results regarding the competitive discipline imposed by the various competitors to the "dominant" firm are strengthened, and our empirical conclusions are seen to be quite conservative.

Third, while the theoretical construct is ideally designed to model the 
market power held by AT\&T for the set of long-distance services provided, the empirical model and data are limited to basic tariffed rates that apply to residential and small business consumers. Other services (for example, WATS) designed for use by high-volume consumers and discount programs available to residential customers are excluded from the empirical analysis. It is generally conceded that competition for these high-end services is keen and that no carrier has significant market power over these services. ${ }^{33}$ To the extent, then, that our empirical model is focused on the low-volume end of the market, our estimates of the Lerner index will, again, tend to err on the high side.

Yet another caveat stems from the presence of regulation in the longdistance market. Specifically, our estimation of the Lerner index is predicated on the ability of the dominant firm to be able to equate marginal cost and the marginal revenue associated with the residual demand curve. To the extent that regulation may be binding, the profit-maximizing price of the dominant firm will be higher than observed prices and the corresponding estimate of the Lerner index is too low. Given, however, the previous empirical research demonstrating that relaxing regulatory controls in this market leads to lower prices, any distortions to our Lerner value estimates, if any, are likely to be minimal. ${ }^{34}$

With these caveats noted, we conclude by suggesting that the approach adopted here of simultaneous estimation of fringe firm supply and market demand elasticities, when combined with marketplace data on market shares, offers a new and potentially useful tool for market power evaluations when more conventional residual demand estimation methods are unavailable.

${ }^{33}$ For a discussion, see Federal Communications Commission, Report and Order, CC Docket 93-197 (1995).

${ }^{34}$ See Alan D. Mathios \& Robert P. Rogers, The Impact of Alternative Forms of State Regulation of AT\&T on Direct-Dial, Long-Distance Telephone Rates, 20 RAND J. Econ. 437, 453 (1989); and Robert Kaestner \& Brenda Kahn, The Effects of Regulation and Competition on the Price of AT\&T Intrastate Telephones Service, 2 J. Regulatory Econ. 363, 377 (1990). Neither of these papers controls for the possibility of endogeneity in the choice of regulatory regime and may, therefore, contain flawed inferences regarding the impact of regulation on prices. An independent and correctly specified test of whether, and the extent to which, regulation is binding is beyond the scope of the present article. As noted by Ward, supra note 2, however, prices for residential and small business services were at their cap for only a relatively small portion of the 1989-91 period. This observation tends to corroborate these prior authors' finding that regulation was not binding during this period. 


\section{APPENDIX}

TABLE Al

VARIABle Names and Definitions

\begin{tabular}{|c|c|c|}
\hline Variable & Definition & Source \\
\hline$Q_{\mathrm{M}}$ & $\begin{array}{l}\text { Interstate switched access minutes of all long-distance car- } \\
\text { riers }\end{array}$ & b \\
\hline$P_{\mathrm{L}}$ & $\begin{array}{l}\text { Real consumer price index for local telephone service } \\
\quad(1982-1984=100)^{*}\end{array}$ & a \\
\hline PHONE & $\begin{array}{l}\text { Number of households with telephone service, measured } \\
\text { in millions }\end{array}$ & b \\
\hline PHONESQ & PHONE*PHONE & \\
\hline$Q_{\mathrm{F}}$ & $\begin{array}{l}\text { Interstate switched-access minutes by carriers other than } \\
\text { AT\&T }\end{array}$ & b \\
\hline$P A$ & $\begin{array}{l}\text { Real price of total access charges per conversation min- } \\
\text { ute } \dagger\end{array}$ & a \\
\hline$P$ & $\begin{array}{l}\text { Average daytime real price of AT\&T's long distance } \\
\text { interstate telephone service for a } 10 \text {-minute } 200 \text {-mile } \\
\text { call } \ddagger\end{array}$ & a \\
\hline$E A$ & $\begin{array}{l}\text { Percentage of total industry lines converted to equal } \\
\text { access }\end{array}$ & b \\
\hline$Y$ & Real disposable per capita income $\S$ & $\mathrm{c}$ \\
\hline$D_{i}$ & Quarterly dummies, $i=2,3,4$ & \\
\hline
\end{tabular}

SourCES.- (a) Federal Communications Commission, Common Carrier Bureau, Industry Analysis Division, Reference Book: Rates, Indexes, and Household Expenditure for Telephone Services (May 1993); (b) Federal Communications Commission, Statistics of Communications Common Carriers, 1991/1992 ed. (released January 1993); (c) Economic Report of the President (1985-94).

* $P_{\mathrm{L}}$ is calculated by deflating the nominal consumer price index for local telephone service with the consumer price index for all goods and services.

$\dagger P_{\mathrm{A}}$ includes originating carrier common line charges, terminating carrier common line charges, and traffic sensitive charges. Note also that $P_{\mathrm{A}}$ is calculated by deflating nominal access charges with the implicit price deflator.

$\ddagger$ Real prices are calculated by deflating nominal prices with the implicit price deflator.

$\S$ Real per capita income is calculated by dividing nominal per capita income with the implicit price deflator $(1982=1)$.

\section{BIBLIOGRAPHY}

Allen, Robert E. Testimony before the U.S. Senate Committee on Commerce, Science, and Transportation, Subcommittee on Telecommunications, September 8, 1993. 103d Congress, 1st Session.

AT\&T Bell Laboratories. "An Updated Study of AT\&T's Competitors' Capacity to Absorb Rapid Demand Growth." Unpublished report. Basking Ridge, N.J.: AT\&T Bell Laboratories, April 1995.

Baker, Jonathan B., and Bresnahan, Timothy F. "Estimating the Residual Demand Curve Facing a Single Firm." International Journal of Industrial Organization 6 (1988): 283-300.

Baker, Jonathan B., and Bresnahan, Timothy F. "Empirical Methods of Identifying and Measuring Market Power." Antitrust Law Journal 61 (1992): 3-16.

Blank, Larry; Kaserman, David L.; and Mayo, John W. "Dominant Firm Pricing 
with Competitive Entry and Regulation: The Case of IntraLATA Toll."' Unpublished manuscript. Knoxville: University of Tennessee, 1995.

Bresnahan, Timothy F. "Empirical Studies of Industries with Market Power." Chapter 17 in Handbook of Industrial Organization, Vol. 2, edited by R. Schmalensee and R. D. Willig. Amsterdam: North-Holland Publishers, 1989.

Federal Communications Commission. Common Carrier Bureau. Industry Analysis Division. "Long Distance Market Share." Unpublished report. Washington, D.C.: Federal Communications Commission, 1992/93.

Federal Communications Commission. Common Carrier Bureau. Industry Analysis Division. "Fiber Deployment Update-End of Year 1993." Unpublished report. Washington, D.C.: Federal Communications Commission, May 1994.

Gatto, J. P.; Langin-Hooper, J.; Robinson, P. B.; and Tryan, H. "Interstate Switched Access Demand." Information Economics and Policy 3 (1988): 333-58.

Hall, Robert E. "The Relation between Price and Marginal Cost in U.S. Industry." Journal of Political Economy 96 (1988): 921-47.

Hall, Robert E. "'Long Distance: Public Benefits from Increased Competition." Unpublished manuscript. Menlo Park, Calif.: Applied Economics Partners, 1993.

Haring, John, and Levitz, Kathleen. "What Makes the Dominant Firm Dominant?" Working paper. Washington, D.C.: Federal Communications Commission, Office of Plans and Policy, 1989.

Hausman, Jerry A. "The Long-Distance Markets Today." Unpublished manuscript. Cambridge: Massachusetts Institute of Technology, November 12, 1993.

Hausman, Jerry; Tardiff, Timothy; and Belinfante, Alexander. "The Effects of the Breakup of AT\&T on Telephone Penetration in the United States." American Economic Review 83 (1993): 178-84.

Hovenkamp, H. "Antitrust Analysis of Market Power with Some Thoughts about Regulated Industries." In Telecommunications Deregulation: Market Power and Cost Allocation Issues, edited by J. R. Allison and D. L. Thomas. Cambridge, Mass.: Ballinger Publishing Co., 1987.

Kaestner, R., and Kahn, B. "The Effects of Regulation and Competition on the Price of AT\&T Intrastate Telephone Service." Journal of Regulatory Economics 2 (1990): 363-77.

Kaserman, David L., and Mayo, John W. "Long Distance Telecommunications Policy: Rationality on Hold." Public Utilities Fortnightly 122 (December 22, 1988): 18-27.

Kaserman, David L., and Mayo, John W. "Long-Distance Telecommunications: Expectations and Realizations in the Post-divestiture Period." In Incentive Regulation for Public Utilities, edited by Michael A. Crew. Boston, Mass.: Kluwer Academic Publishers, 1994.

Kaserman, David L., and Mayo, John W. "Competition and Asymmetric Regulation in Long Distance Telecommunications: An Assessment of the Evidence." Comm Law Conspectus 4 (1996): 1-26.

Katz, M. L., and Willig, R. D. "The Case for Freeing AT\&T." Regulation (JulyAugust 1984): 43-49.

Kmenta, Jan. Elements of Econometrics. 2d ed. New York: Macmillan Publishing Co., 1986. 
MacAvoy, Paul W. "Tacit Collusion under Regulation in the Pricing of Interstate Long-Distance Telephone Services." Journal of Economics and Management Strategy 4 (1995): 147-85.

Mathios, A. D., and Rogers, R. P. "The Impact of Alternative Forms of State Regulation of AT\&T on Direct-Dial, Long-Distance Telephone Rates." RAND Journal of Economics 20 (1989): 437-53.

Norrbin, Stefan. "The Relation between Price and Marginal Cost in U.S. Industry: A Contradiction." Journal of Political Economy 101 (1993): 1149-64.

Porter, Michael E. "Competition in the Long Distance Telecommunications Market." Unpublished report. N.p.: Monitor Company, September 1993.

Porter, Michael E. "Competition in the Long Distance Market: An Industry Structure Analysis." Unpublished report. N.p.: Monitor Company, 1990.

Salop, Steven C.; Brenner, Steven R.; and Roberts, Gary L. "Market Power in the Supply of Long-Distance Telephone Services." Unpublished manuscript. Boston, Mass.: Charles River Associates, 1990.

Saving, Thomas R. "Concentration Ratios and the Degree of Monopoly." International Economic Review 11 (1970): 139-46.

Scheffman, David T., and Spiller, Pablo T. "Geographic Market Definition under the U.S. Department of Justice Merger Guidelines." Journal of Law and Economics 30 (1987): 123-47.

Scherer, F. M., and Ross, David. Industrial Market Structure and Economic Performance. 3d ed. Boston: Houghton Mifflin Co., 1990.

Shepherd, William G. "Long-Distance Telephone Service: Dominance in Decline?"' In Industry Studies, edited by Larry L. Duetsch, pp. 342-63. Englewood Cliffs, N.J.: Prentice Hall, 1993.

Suslow, Valerie. "Estimating Monopoly Behavior with Competitive Recycling: An Application to ALCOA." RAND Journal of Economics 17 (1986): 389-403.

Taylor, Lester D. "Pricing of Telecommunications Services: Comment on Gabel and Kennet." Review of Industrial Organization 8 (1993): 15-19.

Taylor, Lester D. Telecommunications Demand in Theory and Practice. Boston, Mass.: Kluwer Academic Publishers, 1994.

Ward, Michael R. "Measurements of Market Power in Long Distance Telecommunications.' Staff report. Washington, D.C., Federal Trade Commission, Bureau of Economics, 1995.

Worcester, Dean A. “'Why 'Dominant Firms' Decline." Journal of Political Economy 65 (1957): 338-46. 